\title{
Factors Impacting Postgraduate Throughput Rates at a South African University of Technology
}

\author{
T. Khauoe and S. Fore
}

\begin{abstract}
Throughput rates, student retention and dropout rates of postgraduate students remain a critical concern facing higher education institutions around the globe. Higher education institutions continuously strive to find ways in which the various stakeholders can make important decisions to ensure acceleration of throughput rates amongst postgraduate students at these institutions, particularly because the economic crisis relies highly on learned and skillful personnel to stir nations towards developmental goals. Industries requiring skilled personnel are often disappointed by absence of people able to come to task and this result in a poorer industry when compromises are made to fulfil positions. The correlation between education offered and its ability to be imparted effectively is an important consideration for leveraging the South African economy.
\end{abstract}

Keywords - dropout rates, postgraduate students, student retention, throughput rates.

\section{INTRODUCTION}

Low numbers of graduations among postgraduate students has for a while now become a major concern in South Africa, particularly because the economic crisis relies highly on learned and skilful personnel to stir the country towards its developmental goals. Institutions of higher learning as well as the Department of Higher Education (DoHE) have jointly lamented dwindling numbers of postgraduate students failing to make either the finishing line in record time or abandoning their respective courses. These premature departures have been shown to adversely impact on economic activities both in the education sector and in the industry. Continued observations of this behaviour will not only bring into question the credibility of the education sector, but also its reliability to dispose of qualified personnel into the industry. The industry itself stands to suffer the most without an adequately skilled workforce required to propel a technical industry towards desired developments. The correlation between education offered and its ability to be imparted effectively is an important

Manuscript received October 1, 2020.

T. Khauoe is a Masters student at Cape Peninsula University of Technology. Hanover street, Zonnebloem, Cape Town, Western Cape, South Africa.

S. Fore is with Cape Peninsula University of Technology, Hanover street, Zonnebloem, Cape Town, Western Cape, South Africa. consideration for leveraging the South African economy. South Africa, like many other countries, need to improve productivity to become economically competitive [1]. To accomplish these, higher education institutions need to increase cohorts at postgraduate level and invest more in research and technology, as these will lead to a significant increase of required critical skills within the labour sector.

Despite a policy shift by the Department of Higher Education (DoHE) to improve student throughput rate, a substantial number of universities in South Africa are still experiencing high drop-out rates and in some cases, students take longer periods, more than 3 years, to complete their postgraduate studies. Institutions are therefore left with a substantial rate of retention in their systems. A 2008 study was conducted, demonstrated that even the Department of Education (DoE) was impacted negatively by the country's $15 \%$ graduation rate which was then considered the lowest in the world [2].

In realizing the throughput challenges affecting the education sector, the National Development Plan (NDP) 2013 has put in place measures to address these challenges. These measures included recommendations that called for deployment of highly qualified academic staff within institutions of higher learning. Additionally, NDP recommended that institutions double the percentage of doctoral degree holders of staff members in higher education sector from 34 percent to over 75 percent by 2030 [3].

\section{POSTGRAdUATE EDUCATION AND TRENDS}

In the South African context and for the purpose of this research, postgraduate studies or education refers to advanced studies that follows a three-year bachelor's degree and these postgraduate studies include honours, masters and doctoral degrees [4]. The nature of postgraduate studies usually requires independent work and it can be carried-out on a full-time basis or part-time which will also affect completion period [5].

In countries such as the United States of America, if and when students return for an extra additional year to complete their studies, this affects the reputation of the institution among its peers and in the United Kingdom, this problem affects the institutions' external funding recruitment hence, the need to address the issues speedily [6]. The retention rates as well as high dropout rates are also considered as huge waste of resources as the sector is highly subsidized and these finances could be used in expanding the higher education sector systems and to redress past inequalities [1]. When students drop out, the 
financial loss affects the teaching input unit and research output unit, which forms part of government subsidy [7].

Fig. 1 below reflects throughput rates of Masters' students in one of the departments at a university of technology in South Africa between 2012 and 2017. The figure also, clearly observed that, retention of the students has been increasing but the graduation rate has been dropping. There is a substantial increase in the number of registered postgraduate students in universities across the globe, however, this number does not equate to the number of graduates at the same level [8].

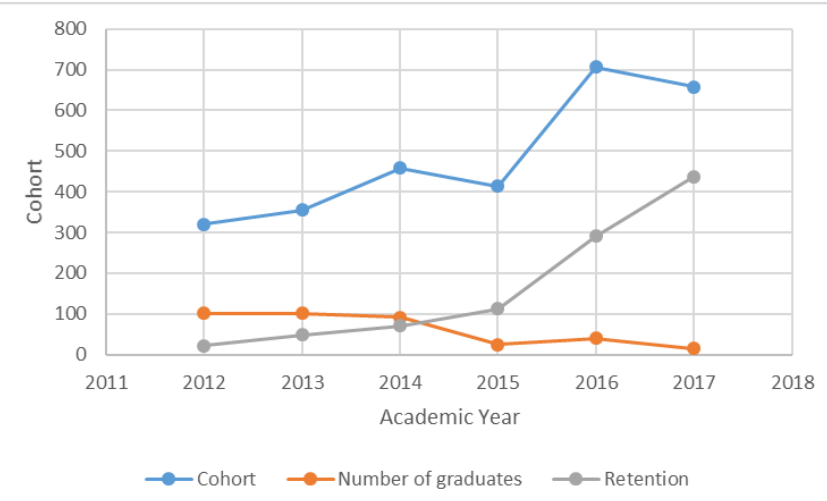

Fig.1. Masters Students Throughput Rate in one of the departments at a University of Technology in South Africa (Source: Records of Masters Students at one of the departments at a University in South Africa)

Findings from other authors, as per fig. 2 below, also emphasis the lack of balance between enrolment and graduation rates of postgraduates within universities of South Africa in general.

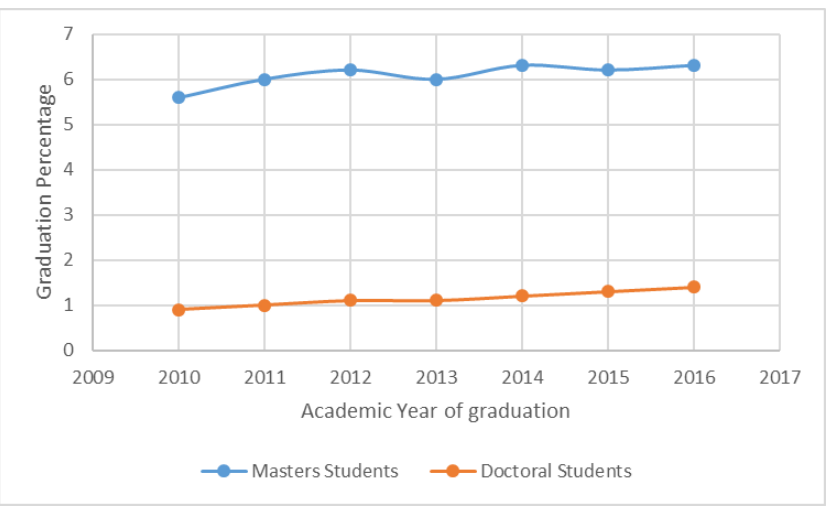

Fig. 2. Graduation rates of postgraduate students at universities in South Africa (Source: Stats SA: March 2019)

On average, as per fig. 3 below, a lot more of postgraduate students take longer than 3.3 years to complete their studies indicating that students do experience certain challenges during their postgraduate studies [8].

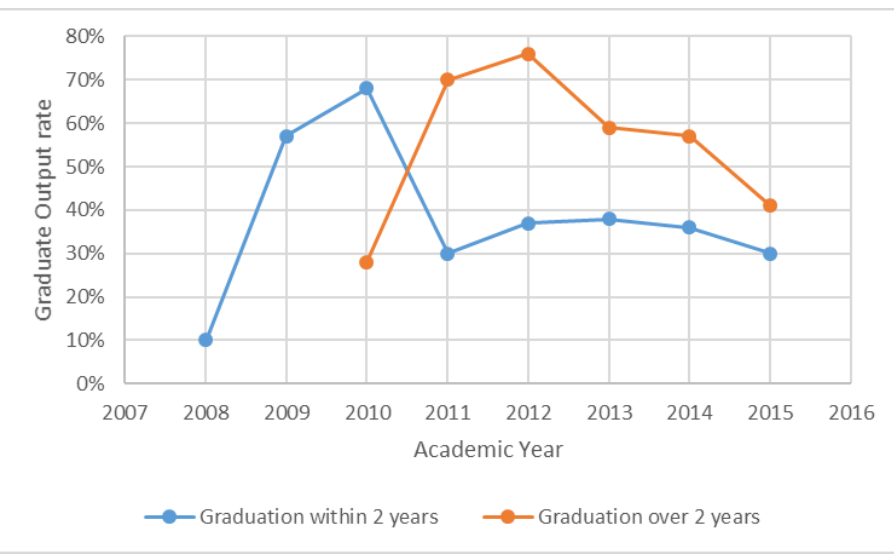

Fig. 3. Graduation rates between 2 year and over 2 years at South African universities (Source: Marnewick and Pretorius 2016)

\section{POSTGRADUATE THROUGHPUT RATES AND TRENDS WITHIN SADC AND SUB-SAHARA REGIONS}

In order to achieve a high level of skills within the Southern African Development Community (SADC) regions, it is necessary and important to increase the number and quality of postgraduate studies [9]. Furthermore, there is a need for upgrading of lecturers in Sub-Sahara countries as a large percentage of lecturers within the institutions are still unqualified [10]. Table 1 below provides an overview of the graduation rates of postgraduate students in the SADC region in 2010 academic year. It is evident that there is a need for intervention as there is a significant decline in throughput or graduation rates for both Master's and Doctoral degrees.

TABLE I. NUMBER OF POSTGRADUATE REGISTRATIONS AND GRADUATIONS IN THE SADC REGION

\begin{tabular}{|l|c|c|c|c|}
\hline \multirow{2}{*}{ Field } & \multicolumn{2}{|c|}{ Masters Degrees } & \multicolumn{2}{c|}{ Doctoral Degrees } \\
\cline { 2 - 5 } & Registration & Graduation & Registration & Graduation \\
\hline $\begin{array}{l}\text { Science, Engineering and } \\
\text { Technology }\end{array}$ & 12840 & 3053 & 3799 & 536 \\
\hline $\begin{array}{l}\text { Business, Management and } \\
\text { Law }\end{array}$ & 17440 & 3625 & 1188 & 124 \\
\hline $\begin{array}{l}\text { Humanities and Social } \\
\text { Sciences }\end{array}$ & 7550 & 3482 & 4695 & 529 \\
\hline Health Sciences & 7550 & 994 & 909 & 114 \\
\hline Other & 392 & 99 & 51 & 23 \\
\hline Total & $\mathbf{5 7 6 6 0}$ & $\mathbf{1 1 2 5 3}$ & $\mathbf{1 0 6 4 2}$ & $\mathbf{1 3 2 6}$ \\
\hline Total excluding SA & 15993 & 3742 & 740 & 143 \\
\hline
\end{tabular}

Source: SARUA Leadership Dialogue Series Volume 2 Number 1 2010

\section{FACTORS IMPACTING POSTGRADUATE THROUGHPUT RATES}

Generally, there has been difficulties in understanding the complexities of the throughput patterns of students at universities and therefore, the reasons for this challenge need to be identified and addressed [11]. It has been difficult for many students to complete their postgraduate studies therefore it is important that students gain a certain level of confidence as it is always seen as an important input in career growth and development [12]. Academic performance (reading ability, motivational factors, learning strategies and learning 
approaches) has been identified as the common barriers that affect throughput rate of postgraduate students [13].

Similarly, student preparedness, financial, student housing, and lack of commitment, conflicting commitments, time management, and student support and student/supervisor relationship are some of the factors that affect student throughput rates [14].

\section{RESEARCH METHODS}

The purpose of the research was to explore and discuss the factors that impact throughput rate of postgraduate students at Masters level. This research therefore employed the mixed method (qualitative and quantitative) approach to allow for the full collaboration of data collection and analysis. This research also used a structured questionnaire, comprising of closed-ended questions and open-ended questions, as this was the only way to engage the participants due to the current pandemic.

\section{RESEARCH FINDINGS}

This research aimed to address the following objectives:

a. Primary objective: To investigate the main factors that affect throughput rate of postgraduate students at a University of Technology. The research identified work commitments, supervisor relationships, lack of time management and research is a grey area as main factors that affect throughput rates. Moreover, respondents also indicated that there were other factors, which affect throughputs rates.

b. Secondary objectives: To examine the current throughput and dropout rates of postgraduate students at a University of Technology and to identify challenges that impact the throughput rate of postgraduate students. This study highlighted the fact many researchers have indicated that more postgraduate students tend to take longer than the maximum period of three years to complete their postgraduate studies due to certain factors as mentioned that affect their studies. This study also found that, as per the figure below, retention of the students has been increasing but the graduation rate has been dropping at one of the universities of Technology in South Africa.

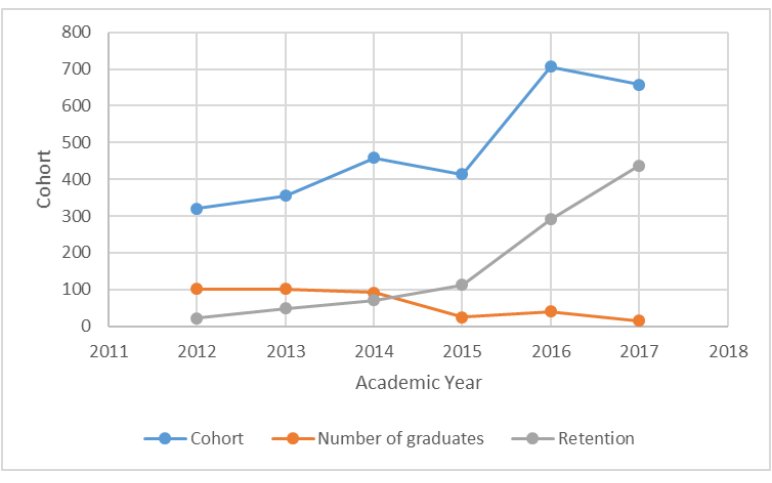

Fig. 4. Masters Students Throughput Rate in one of the departments at a University in South Africa

\section{CONCLUSION}

The primary objectives of the study were to investigate the main factors that affect throughput rate of postgraduate students at a University of Technology. This study therefore, according to the perception of postgraduate students, identified that work commitments, supervisor relationship, lack of time management and the fact that research is a grey area as factors that affected throughput rate of postgraduate students at a University of Technology. The study also found that there were other factors that student did not mention that affect their studies and graduation rates at postgraduate level. The perception of the postgraduate lecturers was also sort, but the researcher received no responses or views.

\section{ACKNOWLEDGMENT}

Firstly, I would to thank the Lord for giving me strength to reaching this far and completing this study. However, most importantly, I would like to thank the Lord for affording me the opportunity of being able to write this dedication.

My sincere gratitude also goes to my supervisor, Mr. Stanley Fore for the support, guidance and much encouragement throughout this research. I would also like to thank my family, from the bottom of my heart, my husband Lesodi and our two sons, Karabelo and Kananelo Lesodi Khauoe, for their unconditional love, great support and for believing in me.

A special thank you to my little sister, Rethabile Pitso, who have spent sleepless nights reviewing this document. I would also like to thank all those that supported this study by responding to the questionnaires. This study would not have been possible without your inputs.

\section{REFERENCES}

[1] R. Sonn. The challenge for a historically disadvantaged South African university to produce more postgraduate students. Continuing and Adult Professional Teacher Development.Walter Sisulu University, Ibika Site. Butterworth, South Africa. Journal of Higher Education. 2016. Volume 30 Number 2. pp 227-241.

https://doi.org/10.20853/30-2-601

[2] M. Letseka and S. Maile. High university drop-out rates: a threat to South Africa's future. HSRC Policy Brief. HSRC Press. 2008. pp 1.

[3] National Development Plan (NDP). 2014. Production of Academics and Strengthening of Higher Education Partnerships with Industry (PASHEPI). Human Resources Development Council of South Africa. 2014. pp 2-14.

[4] Y. Dominquez-Whitehead. Evaluating postgraduate preparation in the South African context. Assessment \& Evaluation in Higher Education. 2015. 40(7):914-927.

https://doi.org/10.1080/02602938.2014.957152

[5] T. S. Hoon, G. Narayanan, G.K. Sidhu, L.P. Choo, C.Y. Fook, and N.N.B.M. Salleh. Students' perceptions toward postgraduate study: A Preliminary Investigation. International Journal of Education, Psychology and Counseling. 2019. Vol.4(30), pp. 123-138.

[6] A. Styger, G.W. van Vuuren, A. Heymans. Case study of Postgraduate Student Dropout rate at South African Universities. International Business \& Economics Research Journal. 2015, vol 14(1), January/February.

https://doi.org/10.19030/iber.v14i1.9027

[7] N. Badsha, N. Cloete. Higher Education: Contribution for the NPC's National Development Plan. 
[8] A. Marnewick, J.H.C. Pretorius. "Masters of Engineering Management: Graduation Rates Lagging behind Growth Rate." 2016 IEEE Frontiers in Education Conference (FIE). 2016, vol. 2016. IEEE, pp 1-8. https://doi.org/10.1109/FIE.2016.7757514

[9] P. Watson. Measuring postgraduate cohort throughput: A case study. University of the Witwatersrand. Faculty of Commerce, Law and Management University of the Witwatersrand. South Africa. SAJHE 22(3)2008 pp 725-739.

[10] M. Sondlo. A comparative study of student retention and throughput in postgraduate distance learning programme. Faculty of Education. University of Pretoria. 2013.

[11] L.C.A. Stoop. Relationships between student throughput variables and properties. South African Journal of Science. 2015, vol. 111, Number 7/8 July/August 2015. https://doi.org/10.17159/sajs.2015/20140336

[12] T.S. Hoon, G. Narayanan, G.K. Sidhu, L.P. Choo, C.Y. Fook, N.N.B.M Salleh. Students' perceptions toward postgraduate study: A Preliminary Investigation. International Journal of Education, Psychology and Counseling. 2019, vol. 4, no. 30, pp. 123-138.

[13] L.J. van Staden, S. Ellis, "Some variables influencing academic achievement: reading, motivation, learning strategies, learning approaches," Journal of educational studies, University of Venda, 2017, vol. 16 , no. 2, pp. $113-131$.

[14] M.A. Bopape, "Factors influencing the through-put rates of masters students at the University of Limpopo," Faculty of management science and law, January 2018.

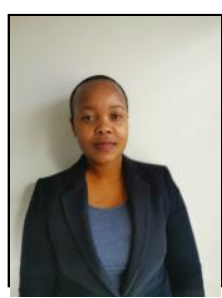

T. Khauoe has BTech: Civil Engineering from Cape Peninsula University of Technology and BTech: Project Management from Cape Peninsula University, in Western Cape, South Africa, in 2006 and 2010 respectively.

She has gained experience in Civil Engineering consultancy as CIVIL ENGINEERING TECHNOLOGIST for the private sector before joining the public sector as CIVIL ENGINEERING PROFESSIONAL for Cape Town Metro Municipality. She later joined the Human Settlement as a PROJECT MANAGER for the N2 Gateway National Housing projects in Cape Town. She is currently employed as a SENIOR PROJECT MANAGER by Drakenstein Municipality, in the Western Cape Winelands, Paarl, South Africa.

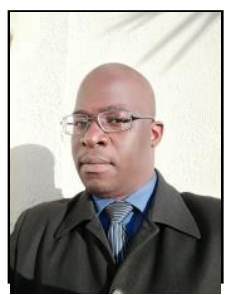

S. Fore is a Lecturer in the Department of Project Management at Cape Peninsula University of Technology (CPUT); department of Project Management. He lectures Project Management to undergraduate students. Prior to joining CPUT, he was lecturing in the Quality and Operations Management department at the University of Johannesburg (UJ) where he taught Operations Management and Quantitative Techniques to undergraduate students. He graduated with a B.Sc.(Honours) from the University of Zimbabwe in and lectured at Gweru Polytechnic from 2002 to 2004. He had previously lectured in the Department of Production Engineering at Chinhoyi University of Technology (CUT) in Zimbabwe, from 2004 to 2008. He completed an MSc in Manufacturing Systems and Operations Management (MSOM), from the University of Zimbabwe in as a staff Development fellow from Chinhoyi University of Technology (CUT). His research interests are in environmental management and operations management with a focus on developing countries. To date, he has successfully supervised several MTech Project Management students. 